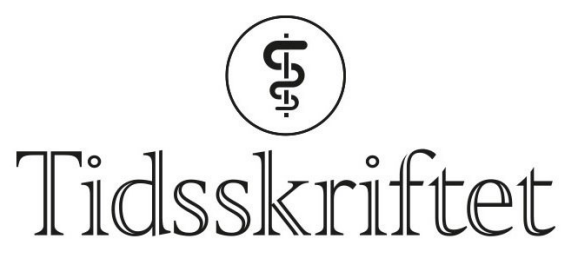

DEN NORSKE LEGEFORENING

\title{
Doktorskole eller medisinstudium?
}

SPRÅKSPALTEN

STEIN FOSSHAUG HERZOG

E-post: stul.herzog@gmail.com

Stein Fosshaug Herzog (f. 1939) er pensjonert spesialist i psykiatri.

En del av mine kolleger omtaler Det medisinske fakultet ved universitetene våre som «doktorskolen». Det synes jeg at vi bør slutte med.

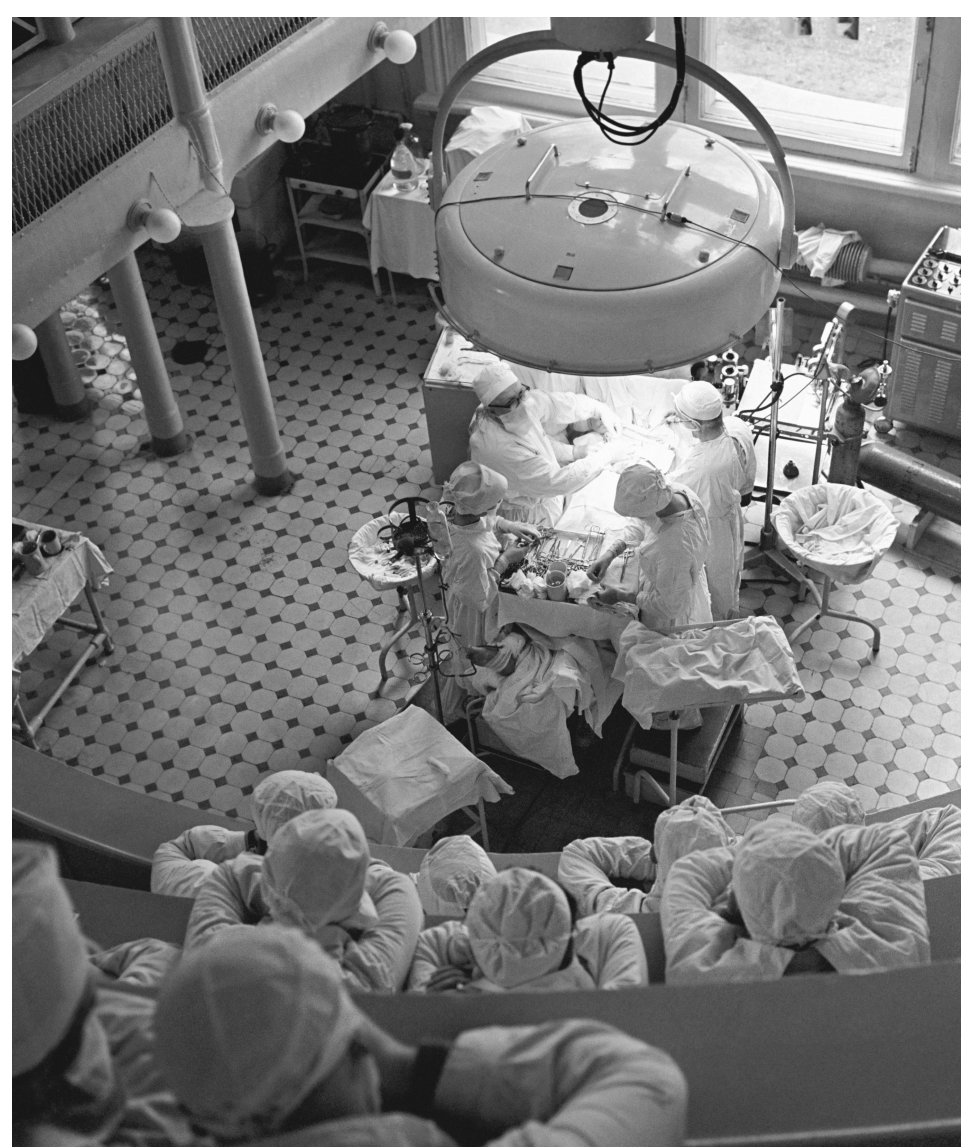

Kirurgisk undervisning ved professor Boris Petrovskij (1908-2004) i Moskva i 1961. Foto: Science Photo Library

Opprinnelig var nok dette en spøkefull nedvurdering, et understatement, av det langvarige, krevende universitetsstudium en legeutdanning er. Men så går det over til å bli et munnhell og jeg føler det blir brukt på en noe kjekkaspreget måte som virker en smule usmakelig: «Hva slags utdanning har du? Jeg har gått på doktorskolen».

Uttrykket «doktorskolen» får meg til å spekulere på hvilke årganger som begynte å bruke 
det. Kanskje var det en vits som oppsto i 1950- og 6o-årene, et slanguttrykk à la «barsk», som vel nå er gått mye ut av bruk igjen? "Doktor" i stedet for "lege” var fortsatt mye brukt før i tiden. Kanskje var det gøy å sette den respekterte tittelen doktor opp imot en skoleutdanning? Jeg håper vi leger vil fortsette å ha respekt for den universitetsutdanningen vi har gjennomført og slutte å bruke begrepet «doktorskolen». Det er ikke lenger «kult», synes jeg.

Publisert: 21. august 2017. Tidsskr Nor Legeforen. DOI: 10.4045/tidsskr.16.0903

(C) Tidsskrift for Den norske legeforening 2020. Lastet ned fra tidsskriftet.no 